\title{
Interactive Equilibrium Modelling A new approach to the computer-aided exploration of structures in architecture
}

\section{Doctoral Thesis}

Author(s):

Lachauer, Lorenz S.

Publication date:

2015

Permanent link:

https://doi.org/10.3929/ethz-a-010453626

Rights / license:

In Copyright - Non-Commercial Use Permitted 
Diss. ETH No. 22536

\title{
Interactive Equilibrium Modelling
}

A new approach

to the computer-aided exploration of structures in architecture

A thesis submitted to attain the degree of

Doctor of Sciences of ETH Zurich

(Dr. sc. ETH Zurich)

\author{
presented by \\ Lorenz Selim Lachauer \\ Dipl. Arch. ETH
}

born on 2.11.1979

citizen of Germany

accepted on the recommendation of

Prof. Dr. Joseph Schwartz (ETH Zurich)

Prof. Dr. Philippe Block (ETH Zurich)

Prof. Dr. Mike Schlaich (TU Berlin) 


\section{Zusammenfassung}

Die vorliegende Dissertation stellt neue Vorgehensweisen für den Entwurf von geometrisch komplexen und zugleich statisch effizienten Tragwerken vor. Computergestützte Entwurfssysteme gestatten es Architekten heute, Gebäude mit spektakulären, oft doppelt gekrümmten Formen zu entwerfen. Durch leistungsstarke numerische Methoden sind Bauingenieure fähig, entsprechend geformte Tragwerke statisch zu dimensionieren. Die häufig in der Planungspraxis disziplinär weitgehend unabhängig voneinander ablaufenden Entwurfs- und Bemessungsprozesse führen oft zu Bauwerken mit ungünstigem Lastabtrag und hohem Bedarf an natürlichen Ressourcen.

Das Ziel dieser Arbeit ist es, eine Methodik des Tragwerksentwurfs zu entwickeln, welche die Prinzipien des Kräftegleichgewichts mit Konzepten des computergestützten Entwerfens kombiniert. Dazu wird ein interaktiver Modellierungsprozess beschrieben, der dem Entwerfer eine schrittweise Annäherung zwischen Entwurfsidee und effizientem Tragwerk ermöglicht. Die Bedeutung der Arbeit liegt einerseits darin, den Graben zwischen freiem architektonischem Entwurf und wissenschaftlichem Tragwerksentwurf zu verringern. Andererseits besteht die Relevanz der Arbeit auch darin, den Entwurfsprozess für geometrisch komplexe Tragstrukturen mit effizientem Lastabtrag in frühen Entwurfsphasen zu systematisieren und zu erleichtern.

Die entwickelten Modellierungsverfahren basieren auf dem statischen Konzept der Fachwerkmodelle, kombiniert mit computergestützten Formfindungsmethoden. In einem ersten Schritt werden massgeschneiderte Methoden für die Modellierung ausgewählter Tragwerkstypologien entwickelt, zum Beispiel für gekrümmte Brücken oder baumartige Stützen. Jede dieser Methoden basiert auf einem klar definierten Konzept des Lastabtrags. Durch die fallweise Anpassung von Standard-Formfindungsmethoden werden die spezifischen Randbedingungen dieser Konzepte in die jeweiligen Modellierungsprozesse eingeschrieben. In einem zweiten Schritt wird eine allgemeine Methode entwickelt, welche es ermöglicht, Modelle mit generischen Randbedingungen $\mathrm{zu}$ erstellen, um damit unterschiedlichen Tragkonzepten gerecht zu werden.

Diese allgemeine Methode zum computergestützten Entwerfen von Tragwerken basiert auf einer neuen Technik zum Lösen von allgemeinen Formfindungsproblemen mit Randbedingungen. Zu diesem Zweck wird die Kraftdichtemethode auf neue Weise erweitert. Bisher bekannte Erweiterungen der Kraftdichtemethode haben grösstenteils das Ziel, Restriktionen aus Konstruktion und Fabrikation in den Formfindungsprozess zu integrieren. Hier werden allgemeine Randbedingungen dazu verwendet, kreative Prozesse für frühe Phasen des Tragwerksentwurfs mit einem hohen Mass an geometrischer Kontrolle auszustatten.

Durch neun prototypische Fallbeispiele wird die Flexibilität der Methode nachgewiesen. In einer ersten Gruppe von Beispielen wird gezeigt, wie es die Methode ermöglicht, die Formenvielfalt von allgemein bekannten 
Tragwerkstypologien zu erschliessen. In einer zweiten Gruppe wird demonstriert, dass sich die Methode darüber hinaus für das Modellieren von neuartigen Tragwerkstypen eignet, die durch die Kombination und das Verschmelzen von bekannten Modellen entstehen.

Folgende Beiträge zum Stand der Forschung sind geleistet worden: massgeschneiderte Methoden zum Modellieren von ausgewählten Tragwerkstypen wurden entwickelt, eine allgemeine Modellierungsmethode basierend auf einer neuen Erweiterung der Kraftdichtemethode wurde formuliert und Fallbeispiele, die den Modellierungsprozess für ausgewählte Tragwerke darstellen, wurden präsentiert. Darüber hinaus stellt das neue Lösungsverfahren für Formfindungsprobleme mit Randbedingungen die Grundlage für die Entwicklung eines computergestützten „Entwurfstools“ für Tragwerke dar.

Schlüsselwörter:

Tragwerksentwurf, computergestützter Entwurf, geometrisches Modellieren, Architekturgeometrie, Gleichgewichtslösungen, Stabwerksmodelle, Formfindung unter Randbedingungen, Kraftdichtemethode 


\section{Abstract}

In this dissertation, new approaches to the design of non-standard building structures with efficient static behaviour are presented. Computer-aided modelling tools enable architects to design spectacular buildings with complex geometry; through strong numerical methods, civil engineers are able to statically analyse and design corresponding structures. The often strong separation between architectural and structural design processes largely results in inefficient structural behaviour and high consumption of resources.

The aim is to develop a structural design methodology which combines principles of static equilibrium with computer-aided design concepts. For this purpose, an interactive modelling approach is described, enabling the designer to iteratively bring together design idea and efficient structural behaviour. On the one hand, the relevance of this dissertation lies in its contribution to reducing the gap between free architectural design and scientific structural design. On the other hand, the relevance lies in the systematisation and facilitation of the design process for geometrically complex building structures with efficient force flow.

The presented modelling approaches are built upon the conceptual framework of truss models, combined with computational form-finding methods. In a first step, tailored equilibrium modelling methods for selected typologies of structures, e.g. curved bridges or branching columns, are developed. Each of these modelling methods is based on well-defined structural concepts. Through customised, case-specific adaptation of standard formfinding techniques, the boundary conditions of the underlying structural concepts are inscribed in these interactive modelling processes. In a second step, a general equilibrium modelling approach is developed, which allows generic boundary conditions to be defined to address different structural concepts.

This general modelling approach is based on a new technique to solve formfinding problems with constraints both on the form and on the inner forces. For this purpose, the Force Density Method has been extended in a new way. Previously, several approaches were formulated in order to add boundary conditions to the Force Density Method, but these were largely driven by specific construction and fabrication properties. Here, general constraints are used to enable early-stage structural design explorations with a high degree of geometric control.

The flexibility of the new method is demonstrated in nine prototypical case studies. The first group of cases demonstrates that the method enables the exploration of the inherent geometric freedom of renowned structural typologies. The second group of cases demonstrates that the method is also suited for creating new typologies, by combining and merging given structural models.

The following contributions to the body of knowledge have been made: tailored modelling approaches for selected structural typologies were 
developed; a general equilibrium modelling approach based on a new extension of the Force Density Method was formulated; case studies illustrating the modelling process of selected structures were presented. Furthermore, the new solving technique for form-finding problems with boundary conditions establishes the conceptual basis for a new computer-aided structural design tool.

Keywords:

structural design, computer-aided design, geometric modelling, architectural geometry, equilibrium solutions, strut-and-tie models, constrained form finding, Force Density Method 